\title{
Villanova Engineering Service Learning
}

\author{
Jordan Ermilio, PE, RPCV \\ Director, Engineering Service Learning \\ College of Engineering \\ Villanova University \\ Jordan.Ermilio@Villanova.edu
}

\author{
Garrett Clayton, $\mathrm{PhD}$ \\ Associate Professor \\ Department of Mechanical Engineering \\ Villanova University \\ Garrett.Clayton@Villanova.edu
}

\author{
Mahmoud Kabalan \\ $\mathrm{PhD}$ Candidate \\ College of Engineering \\ Villanova University \\ Mahmoud.Kabalan@Villanova.edu
}

\begin{abstract}
The College of Engineering at Villanova University has a long history of providing technical services to support humanitarian initiatives. For over twenty years, engineering faculty and students have been participating in engineering outreach activities, which are commonly referred to as Engineering Service Learning. In 1991, a small group of engineering students and faculty traveled to work with the Cheypo-Bayano Mission in Panama. Students who graduate were excited to return to Panama to see their projects through to completion, which included a large water supply distribution system and a bridge for a small remote community in the region. At that time, the concept of servicelearning did not exist, but due to the Augustinian Heritage at Villanova University, these types of activities have been strongly encouraged. In fact, the idea of ministry has been a strategic part of the university' mission since 1979, and at the present time, there are an estimated 800 students and advisors who travel annually to over 40 locations globally (including the US) to volunteer on service projects. These projects include engineering and non-engineering activities, but the success of the engineering service learning program has been significantly influenced by the culture of service that exists at Villanova University and the Augustinian values which are routed in service to society.
\end{abstract}

Index - engineering service learning, partnerships

"The degree to which you are concerned with the common good rather than your own, is the criterion by which you can judge how much progress you have made."

- The Rule of Augustine 


\section{INTRODUCTION}

The Villanova Engineering Service Learning (VESL) Program was formally established in 2011 when the Dean of Engineering created a Director of Service Learning Position at the College. Prior to this, Engineering Service Learning entailed senior design capstone projects with a one or two semester commitment. At the present time, engineering service learning includes curricular and non-curricular activities, and there are a number of courses that have integrated service projects within their syllabi. In addition to integrated service learning, student who are interested in continuing their commitment to humanitarian initiatives are provided opportunities for full immersion through summer service internships, year of service assignments and graduate research projects. These initiatives along with a partnership approach to project implementation have been key components to creating continuity within the program as well as a breadth and depth of opportunities for all program stakeholders.

Initially, students who participated in one-week service break trips through the larger university initiative were excited and challenged to do more. These students often solicited faculty to get involved with various projects, which ultimately led to the integration of service learning with senior design capstone courses in Civil and Mechanical Engineering. Projects in 2001 included the construction of an orphanage in Honduras and the design of water supply and distribution systems in Nicaragua. At the present time, the College of Engineering has 12 ongoing initiatives in 6 different countries and more than 300 students participate in a service learning project in some capacity every year. This paper summarizes information about the VESL program and includes lessons learned while establishing a comprehensive approach to engineering service learning at Villanova University.

\section{SUMMARY OF PROJECTS}

Since 2011, engineering students and faculty have worked on 29 different projects with 14 different project partners in 10 different countries including the United States. These projects include STEM outreach to local schools in the Philadelphia area as well as in Haiti, Cambodia and Madagascar. Student design projects have included community water supply, school construction, renewable energy, transportation and humanitarian technology projects in multiple countries. These projects have been laterally and vertically integration across the engineering disciplines with projects that include Mechanical, Civil \& Environmental, Electrical \& Computer and Chemical Engineering students. In addition to undergraduate student design projects, recent initiatives have included graduate projects in the field of Sustainable Engineering. These initiatives include research on Sustainable Water Supply in Developing Communities, Low-cost Renewable Energy Technologies, Communication Systems for Rural Healthcare and the Impact of Engineering Service Learning on Local Communities.

At the present time, VESL has 12 ongoing initiatives in 6 different countries, not including the United States. In Asia, students are working with three different organizations; the Caramanico Foundation (CFC), and the Golden West Humanitarian Foundation (GWHF) in Cambodia, and Profugo in India. In Africa, students are working with two different organizations; Catholic Relief Service (CRS) in Madagascar, and Wells for Relief (WfR) in Ghana. In Central America, students are working with Water for Waslala and Asociaciûn de Desarrollo Integral y Sostenible in Nicaragua, and the Cheypo Bayano Mission in Panama. Table 1 below summarizes ongoing initiatives during the 2014/15 academic year. 
TABLE 1

SUMMARY OF 2014/15 VESL INITIATIVES

\begin{tabular}{|c|c|c|}
\hline Location & Project Partner & \begin{tabular}{|c|}
2014 Projects \\
\end{tabular} \\
\hline $\begin{array}{l}\text { Ratanakiri, Cambodia, } \\
\text { Since } 2012\end{array}$ & $\begin{array}{l}\text { Caramanico Foundation } \\
(\mathrm{CFC})\end{array}$ & $\begin{array}{l}\text { School Construction, Water Quality } \\
\text { Analysis and STEM }\end{array}$ \\
\hline $\begin{array}{l}\text { Kampong Chnang, } \\
\text { Cambodia, Since } 2012\end{array}$ & $\begin{array}{l}\text { Goldenwest Humanitarian } \\
\text { Foundation (GWHF) }\end{array}$ & $\begin{array}{l}\text { Explosive Ordnance Disposal Robot, } \\
\text { Mobile Remediation Process, National } \\
\text { STEM Festival }\end{array}$ \\
\hline $\begin{array}{l}\text { Wayanad, India, } \\
\text { Since } 2013\end{array}$ & Profugo & $\begin{array}{l}\text { Bio-gas digester design and Water } \\
\text { Quality Analysis }\end{array}$ \\
\hline $\begin{array}{l}\text { Madagascar } \\
\text { Since } 2014\end{array}$ & $\begin{array}{l}\text { Catholic Relief Services } \\
\text { (CRS) }\end{array}$ & $\begin{array}{l}\text { Technical support for water supply } \\
\text { projects, sustainable WASH research and } \\
\text { capacity building }\end{array}$ \\
\hline $\begin{array}{l}\text { Lower Volta, Ghana } \\
\text { Since } 2014\end{array}$ & Wells for Relief (WfR) & Sustainable Handpumps. \\
\hline $\begin{array}{l}\text { Waslala, Nicaragua, } \\
\text { Since } 2004\end{array}$ & Water for Waslala (WfW) & $\begin{array}{l}\text { Technical support for water supply } \\
\text { projects, sustainable WASH and capacity } \\
\text { building }\end{array}$ \\
\hline $\begin{array}{l}\text { Waslala, Nicaragua, } \\
\text { Since } 2011\end{array}$ & $\begin{array}{l}\text { Asociaciûn de Desarrollo } \\
\text { Integral y Sostenible (ADIS) }\end{array}$ & Telehealth for rural health clinics \\
\hline $\begin{array}{l}\text { Torti, Panama } \\
\text { Since } 1991\end{array}$ & Cheypo Bayano Mission & $\begin{array}{l}\text { Water Resources Master Plan, Bridge } \\
\text { Design }\end{array}$ \\
\hline
\end{tabular}

\section{Student and Faculty Involvement}

Table 2 below shows a summary of the total number of students and advisors who have participated in VESL projects since 2011, not including the current academic year Using the 2011/12 Academic Year as the benchmark, student participation in VESL has increase by $28 \%$ and $162 \%$ in the following two years. The involvement of faculty and other external advisors has also increased significantly and represents a 35\% and $48 \%$ increase in participation for the same period. It is important to note that many students participate in engineering service learning projects for more than one semester and more than one year. As a result, the numbers in Table 2, represent the capacity, or the bandwidth of the VESL program, rather than the total number of students impacted.

TABLE 2

SUMMARY OF STUDENT AND FACULTY PARTICIPATION

\begin{tabular}{|c|c|c|c|}
\hline \multirow{2}{*}{$\begin{array}{c}\text { Academic } \\
\text { Year }\end{array}$} & \multicolumn{3}{|c|}{$\begin{array}{c}\text { Total People Involved } \\
\text { Curricular \& Non-Curricular }\end{array}$} \\
\cline { 2 - 4 } & Students & Advisors & Total \\
\hline $2011 / 12$ & 170 & 23 & 193 \\
\hline $2012 / 13$ & 217 & 31 & 248 \\
\hline $2013 / 14$ & 445 & 34 & 479 \\
\hline Total: & 832 & 88 & 920 \\
\hline
\end{tabular}


An important consideration when evaluating student and faculty involvement is the dynamic nature of both project partners and curricular changes from year to year. Figure 1 below shows a summary of the different types of student involvement along with the total number of students from semester to semester. The variations with respect to curricular participation and thus the total number of students, can best be attributed to the integration of VESL projects in different courses from semester to semester. The most significant increase is seen in the fall of 2013 because of the integration of service learning in two core-courses during that semester. Prior to this, the majority of curricular projects included senior design capstone courses. For example, in the spring of 2013, a total of 54 students participated in a class that included an engineering service project. These courses included a number of international senior design projects, an independent study, an engineering ethics course and some local senior design projects. During the summer of 2013, a number of faculty decided to include a service-learning project in their core courses for the following year. As a result, the following academic year shows a significant increase in student participation.

During the Fall 2013 semester, a total of 235 students participated in a curricular-based VESL project. This increase is attributed to two classes (fluid mechanics and engineering analysis and design) that integrated a service-learning mini project into their curriculum. It is important to reiterate that, whether a class has integrated a mini project or a semester long project into their course work, a single student in a class is counted as one participant, regardless of the extent of the participation. In addition to this, if a student were working on a project in different classes, then this student would be counted twice, using the current methods of evaluating student participation.

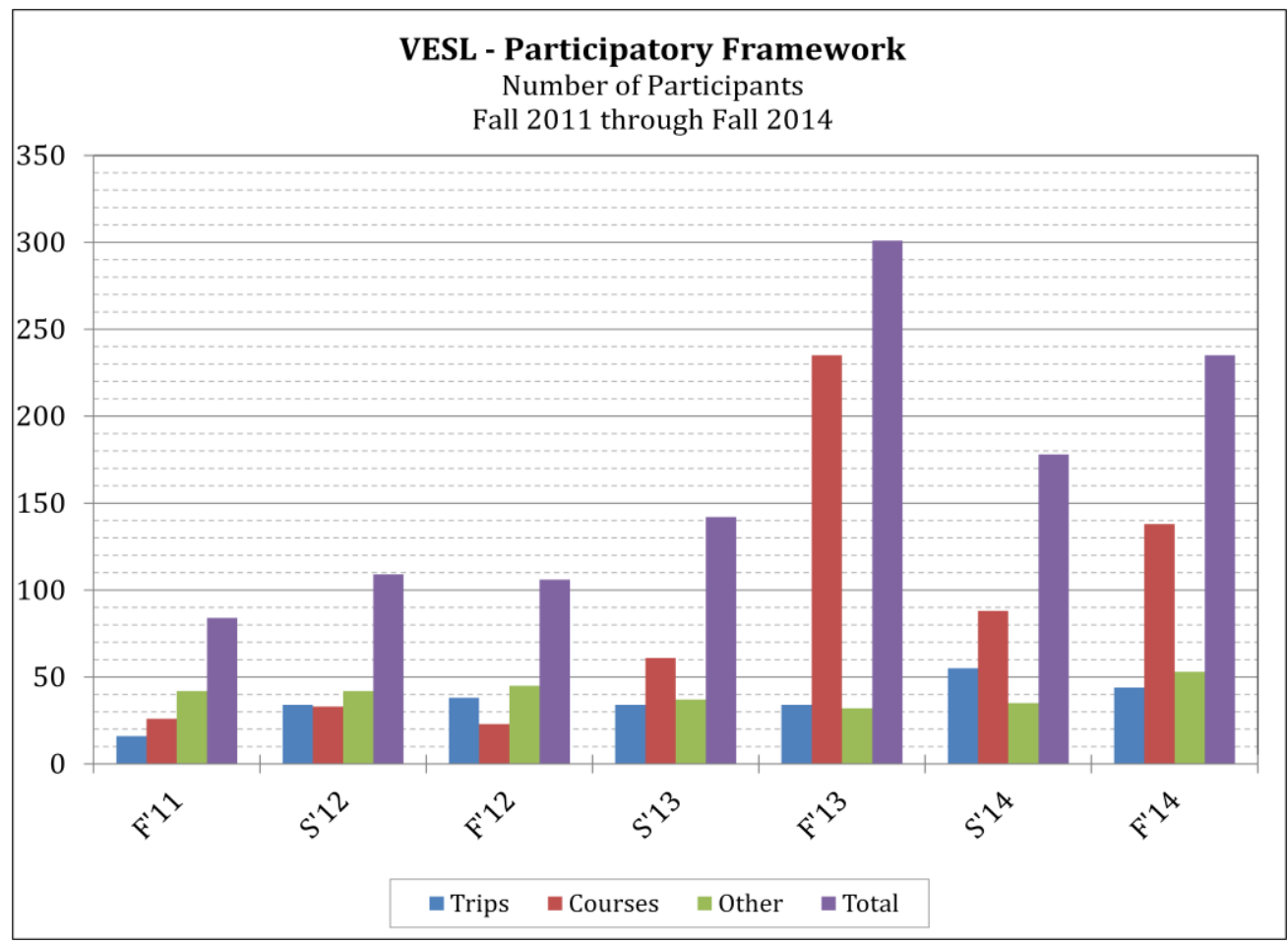

FIGURE 1

STUDENT PARTICIPATION IN THE VESL PROGRAM BASED ON TYPE OF ACTIVITY 


\section{Partnership Approach}

The key to the success of the VESL program has been the focus that faculty and staff have on creating programs and partnerships rather than projects. Whereas projects are an integral component of any engineering service learning initiative, it is important to work with project partners who understand the limitations of a student design team as well as the academic nature of a university partnership. There are a number of mechanisms for students to get involved with a particular project and the project partner needs to understand both the potential and the limitations with respect to each. Having annual coordination and planning meetings with project partners is an excellent way to define the scope of particular projects and to ensure short-term success with a long-term vision.

An important part of a successful program is identifying partners who have the capacity to implement a project. In most cases community development requires the continuous support and the permanent presence of qualified project partners. Qualifications with respect to project partners should be assessed in terms of both financial and human resources. In addition to this, the project partner's ability to work with students and their understanding of academia should also be considered. Whereas students and faculty can provide innovative technical support that focuses on engineering design, capacity building and research; they cannot replace development practitioners, who have expertise appropriate to the local context of the problem. A team of students also cannot replace strategic fundraising initiatives, which are essential to the success of a community development project.

Finally, it is important to prioritize the needs of the local community when planning project activities particularly, as it relates to project implementation. Whereas, engagement with community beneficiaries is important, in that immersion experiences are an excellent learning opportunity for both community members and students, an academic calendar only provides for limited opportunities for field related activities. As a result, project partners should be aware of their role in terms of implementing project activities. Student and faculty teams can participate and contribute to the process in valuable ways but, ultimately it is the project partner who understands the local context best, and it is the project partners who should be in charge of implementation.

To some extent, the question of ethics in terms of the roles and responsibilities of students and faculty should be considered. One of the fundamental canons in engineering ethics is providing engineering services within one's area of competence. On one side, it could be argued that fundamentals in terms of engineering design are universal and thus providing a design service for any part of the world is "within one's area of competence", as long as the faculty advisor is within their respective discipline. The same cannot be said however for students who are still developing their area of expertise. The same can also not be said with respect to local codes and regulations, particularly with respect to project implementation, which can be very site specific. In fact, one of the objectives of this paper is to open a discussion with the academic community about the ethics of engineering service learning and the role of engineering students and faculty with respect to service learning projects. In particular, when engineering service learning includes international projects, it is even more important to work with a partner that understands the local context and thus, identifying and coordinating with project partners becomes a very important aspect of any successful program.

Table 3 below shows a list of current VESL partners and also identifies the VESL project focus along with highlights from this work. 
International Journal for Service Learning in Engineering Special Edition, pp. 334-353, Fall 2014

ISSN 1555-9033

TABLE 3

LIST OF PROGRAM PARTNERS AND VESL PROJECTS

\begin{tabular}{|c|c|c|c|}
\hline Who, Where, When & Partner's Mission & VESL Projects & Coordination Frequency \\
\hline $\begin{array}{l}\text { Caramanico Foundation } \\
\text { Ratanakiri, Cambodia, } \\
\text { Since } 2012\end{array}$ & $\begin{array}{l}\text { Improve the quality of } \\
\text { educational programs } \\
\text { and develop a model } \\
\text { for schools }\end{array}$ & $\begin{array}{l}\text { Design and construction of } \\
\text { a preschool with integrated } \\
\text { water and sanitation } \\
\text { facilities and STEM } \\
\text { Education }\end{array}$ & $\begin{array}{l}2 \text { hours quarterly with } \\
\text { regular monthly updates } \\
\text { Total: } 20 \text { hours annually } \\
\text { Status: Ongoing }\end{array}$ \\
\hline $\begin{array}{l}\text { Golden West } \\
\text { Humanitarian } \\
\text { Foundation } \\
\text { Kampong Chnang, } \\
\text { Cambodia, Since } 2012\end{array}$ & $\begin{array}{l}\text { Research and } \\
\text { Development of low- } \\
\text { cost un-exploded } \\
\text { (UXO) ordnance } \\
\text { technology }\end{array}$ & $\begin{array}{l}\text { Explosive Ordnance } \\
\text { Disposal Robot } \\
\text { UXO Remediation }\end{array}$ & $\begin{array}{l}1 \text { day, annually with } \\
\text { quarterly discussions } \\
\text { Total: } 12 \text { hours annually } \\
\text { Status: Ongoing }\end{array}$ \\
\hline $\begin{array}{l}\text { Philippine Rural } \\
\text { Reconstruction } \\
\text { Movement, SITMO } \\
\text { Ifugao, Philippines } \\
\text { Since } 2006\end{array}$ & $\begin{array}{l}\text { Enhance the capacity } \\
\text { of rural communities } \\
\text { in planning and } \\
\text { implementation }\end{array}$ & $\begin{array}{l}\text { Haiyan Relief, Engineered } \\
\text { Landfill, Micro Hydro } \\
\text { Electrification }\end{array}$ & $\begin{array}{l}\text { Not Applicable } \\
\text { Status: On Hold }\end{array}$ \\
\hline $\begin{array}{l}\text { Profugo } \\
\text { Wayanad, India, } \\
\text { Since } 2013\end{array}$ & $\begin{array}{l}\text { Improving quality of } \\
\text { life and cultivating } \\
\text { expertise }\end{array}$ & $\begin{array}{l}\text { Bio-gas digester } \\
\text { Water Quality Testing and } \\
\text { Analysis }\end{array}$ & $\begin{array}{l}1 \text { hour bi-annually with } \\
\text { updates quarterly } \\
\text { Total: } 6 \text { hours annually } \\
\text { Status: New Project }\end{array}$ \\
\hline $\begin{array}{l}\text { Water for Waslala } \\
\text { Waslala, Nicaragua, } \\
\text { Since } 2004\end{array}$ & $\begin{array}{l}\text { Ensure sustainable } \\
\text { access to safe drinking } \\
\text { water }\end{array}$ & $\begin{array}{l}\text { Technical support for } \\
\text { water supply projects } \\
\text { Water technology } \\
\text { Sustainable WaSH }\end{array}$ & $\begin{array}{l}1 \text { day annually, } 2 \text { hours } \\
\text { quarterly with monthly } \\
\text { updates } \\
\text { Total: } 28 \text { hours annually } \\
\text { Status: Ongoing }\end{array}$ \\
\hline $\begin{array}{l}\text { Asociaciûn de Desarrollo } \\
\text { Integral y Sostenible } \\
\text { Waslala, Nicaragua, } \\
\text { Since } 2011\end{array}$ & $\begin{array}{l}\text { Local implementing } \\
\text { partner for water } \\
\text { supply and mobile } \\
\text { health projects }\end{array}$ & $\begin{array}{l}\text { Nova Mobile Health: a } \\
\text { low-cost communication } \\
\text { system to increase access } \\
\text { to health care }\end{array}$ & $\begin{array}{l}2 \text { hours bi annually with } \\
\text { quarterly updates } \\
\text { Total: } 8 \text { hours annually } \\
\text { Status: Ongoing }\end{array}$ \\
\hline $\begin{array}{l}\text { Cheypo Bayano Mission } \\
\text { Torti, Panama } \\
\text { Since } 1991\end{array}$ & $\begin{array}{l}\text { Development of local } \\
\text { infrastructure: roads, } \\
\text { bridges, water supply } \\
\text { and schools }\end{array}$ & $\begin{array}{l}\text { Water Resources Master } \\
\text { Plan } \\
\text { Bridge Design }\end{array}$ & $\begin{array}{l}2 \text { hours bi annually with } \\
\text { quarterly updates } \\
\text { Total: } 12 \text { hours annually } \\
\text { Status: Ongoing }\end{array}$ \\
\hline $\begin{array}{l}\text { Catholic Relief Services } \\
\text { Haiti and Madagascar } \\
\text { Since } 2011\end{array}$ & $\begin{array}{l}\text { Assist poor and } \\
\text { vulnerable } \\
\text { populations, fight } \\
\text { poverty and nurture } \\
\text { peace }\end{array}$ & $\begin{array}{l}\text { WASH Training } \\
\text { Water System Design } \\
\text { Sustainable WaSH }\end{array}$ & $\begin{array}{l}2 \text { day annually with } \\
\text { quarterly discussions } \\
\text { Total: } 20 \text { hours annually } \\
\text { Status: Ongoing }\end{array}$ \\
\hline $\begin{array}{l}\text { Wells for Relief } \\
\text { Lower Volta, Ghana } \\
\text { Since } 2014\end{array}$ & $\begin{array}{l}\text { Alleviate poverty } \\
\text { through the } \\
\text { development of } \\
\text { groundwater }\end{array}$ & Sustainable Handpumps. & $\begin{array}{l}1 \text { hour quarterly with } \\
\text { monthly updates } \\
\text { Total: } 16 \text { hours annually } \\
\text { Status: New Proiect }\end{array}$ \\
\hline
\end{tabular}

Included in this table is a summary of the planning and coordination sequence associated with each project partner. From this information, it can be estimated that a project partnership requires over 15 hours of planning and coordination on average, annually. The range of time spent coordinating various program activities is significant, and often depends on the nature of the relationship with the project partner. Upon initial review, it appears that the well-established partnerships require more time for coordination, potentially because there are more ongoing initiatives that require planning. At the same time, the oldest partnership in Panama (Since, 
1991) required slightly less than the average at 12 hours of annual planning and coordination. These figures however, do not include input from all of the stakeholders and can best be described as the author's best assessment based on experience, rather than verified data. It is also important to note that these figures do not include time spent during field related immersion activities where a lot of discussions occur about potential projects. Student's time is not included and the figures are not adjusted for the number of people involved in planning and coordination meetings.

\section{THE VESL APPROACH}

Within the VESL program, we refer to our teams as being "catalysts" in the development process. The objective is not to introduce and create development projects, but rather to support ongoing local initiatives and to make them better by introducing innovation, engineering design and analysis. We teach our students to support "Local Solutions for Local Problems" and this concept has established itself across curricular service learning initiatives throughout Villanova University via interdisciplinary service learning projects that also include social entrepreneurship. A good example of how this approach was implemented is in the Philippines, where we worked with a non-government organization in Northern Luzon to identify local innovators that were solving problems in their community. Rather than asking students to "innovate" on problems that they did not necessarily understand (eg., bottom of the economic pyramid issues), we asked to them to work with our partners to identify local innovators who were already solving problems in their community. Only then could our teams provide innovation and engineering design services to assist the local innovators.

During this initiative, we met with Luis Cabigat, a local man who had constructed a small turbine for milling rice and generating small amounts of energy. Our teams did a reverse engineering analysis of his turbine and introduced controls and a better manufacturing process to improve reliability and performance. VESL students also met with Fernando Bahatan who created a distillery for extracting essential oils from lemon grass. Our teams worked with him to improve the thermal efficiency of the process by introducing pre-heated water from the condenser, into the boiler and by increasing the surface area of the heating zone for the boiling process.

In many cases, existing technologies are needed to solve a particular problem. In these situations, we introduce educational activities that will support our local partners to come to their own conclusions about the selection of a certain technology. For example, in 2004 when a team of engineering students and faculty traveled to a remote region of Nicaragua called Waslala, it did not take long to identify water quality problems in the region. Rather than imposing external solutions to this local problem, we stayed focused on the current initiatives of the local team, which was to improve access to water through gravity-driven water networks. Our understanding was that the water quality issue could be addressed retroactively and that increasing the quantity of water available was equally as important. Independently, the team put together a water testing protocol and then trained the local team on sampling and analysis. Over time, the local team realized the extent of the water quality problem and proposed a number of potential solutions. The VESL team then helped to evaluate different proposals and piloted a number of water treatment technology projects. 
For Engineering Service Learning to be effective, the leadership team focuses on both program goals and project activities. Within the VESL program, we have three strategic objectives, which support the mission of the program.

Mission: To engage engineering students in unique learning opportunities that reinforces engineering fundamentals, a commitment to life-long learning and service to society.

Objective 1: Create Service Learning Opportunities for Every Engineering Student.

Objective 2: Establish Financial Sustainability for the VESL Program.

Objective 3: Demonstrate Best Practices in Engineering Service Learning.

In addition to having strategic objectives, an action plan has been created to meet each of the objectives specifically. Action items include things like integrating projects into existing coursework, establishing high quality project partners, creating financial plans and publishing papers. The result is, that student can participate in humanitarian initiatives as active members of a team rather than driving community development initiatives, which should be communitydriven. This does not mean that student-driven initiatives do not exist. On the contrary, when students are put into a position to be successful; student-driven initiatives flourish within the student's area of expertise, which is innovation, rather than community development. This ultimately allows students to innovate within a specifically defined project scope. Student leaders also have the opportunity to drive certain initiatives by participating in the planning and coordination process with project partners, during the initial stages of a project. This provides a well-structured format for project planning because faculty advisors are better qualified to understand how student teams can support the needs of the partners. Notably absent from the above program objectives are impacts in the community. Whereas, providing engineering services that have an impact are important, determining how to evaluate project outputs is often beyond the scope of an undergraduate student team. It is for this reason that current efforts to integrate engineering service learning initiatives into the graduate program in Sustainable Engineering are currently being explored which is included in the action plan associated with the third objective.

As a result of this approach, student projects are rooted in engineering fundamentals and students learn to apply engineering design and analysis to solve complex problems. In addition, this approach has provided our teams an opportunity to create lasting partnerships with various organizations that understand the value of working with an academic partner. When program partners are in charge of implementation, VESL teams can focus on engineering. We simply ask our partners; "What are you currently working on, and how can we help?" It is then up to the students and faculty to connect engineering design and analysis into the services that are provided.

In May of 2014, the VESL program worked with a Hubert Humphrey Fellow who conducted a SWOT analysis of the entire program as a part of their professional practicum. During this analysis, a Likert survey was constructed and various stakeholders were asked to provide feedback about the strengths and weaknesses of the VESL program. Table 4 below presents a summary of the result including input from partners, faculty and students. All program stakeholders were asked similar questions about their perceived strengths and weaknesses about working with VESL teams. Interestingly, there are some common results as well as some conflicting opinions. Both the students (71.4\%) and faculty (75\%) agreed that having 
multidisciplinary projects with engineers and non- engineers is a strength of the program, and both agreed (71.4\% and 75\% respectively) that there is a high level of student participation and interest in the program. Students and faculty disagree, however with respect to faculty participation. Students felt that the level of faculty participation is "a strength" (71.4\%) and faculty felt that it was a weakness (50\%). All stakeholders agreed that having multiple initiatives simultaneously was "a strength". With respect to weaknesses, both the program partners (50\%) and students (42.9\%) agreed that accountability for project deliverables should be emphasized more.

Another important aspect of any engineering service learning program is providing opportunities to engage in field related project activities. Since 2011, the VESL Program has implemented a post-project evaluation so that participants can provide feedback about different aspects of SL field experiences. During this time, a total of 206 students participated in field related immersion activities and a total of 32 students provided feedback using a Likert scale, which was created to gauge the student's perception about the applications process, orientation, field logistics, project activities and local partners. The definition of "strength" was identified as being any response that was greater than or equal to 4 out of a total score of 5 points. A "weakness" was defined as any score that was less than or equal to 3 out of 5 points. In addition to this, open-ended questions were asked about the student's perception about how the experience impacted their personal, professional and academic growth.

Whereas the program received positive feedback on all aspects of the service learning experience some strengths and weaknesses can still be identified. The results indicate that the participants surveyed had a positive experience and the total program evaluation score averaged 4.43 out of 5 total points. In addition to this, more than $80 \%$ of the students thought that all aspects of the SL experience were "strong" with the exception of one area. The most successful component was in the area of academic growth where, $96.7 \%$ of the respondents reported that the experience of working with the advisor was excellent. Interestingly, $90.6 \%$ of the students also reported that the experience gave them a better appreciation of engineering and academics. Another strength that can be highlighted is associated with fieldwork during project activities, where $96.9 \%$ of the respondents reported that the housing is excellent and $90.6 \%$ reported that project partners were excellent. Areas for improvement can also be identified from these results. Whereas, $62.5 \%$ of the students reported that the orientation process was excellent, $37.5 \%$ reported that it was a weakness. Also, 18.8\% of the students felt that the project that they were working on did not have a big impact on the community. Table 5 summarized the results and highlights the four strengths and two weaknesses that can have been identified through this survey. 
TABLE 4

SUMMARY OF STAKEHOLDER STRENGTHS AND WEAKNESS EVALUATION

Note: the sample size is too small for research purposes ( $n=6, n=8$ and $n=7$ respectively).

\begin{tabular}{|c|c|c|c|}
\hline & Question & Strength & Weakness \\
\hline \multirow{4}{*}{ 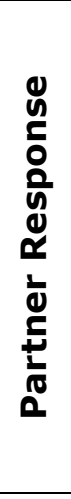 } & $\begin{array}{l}\text { The engineering student teams provide sufficient technical } \\
\text { assistance during all stages of the project cycle; } \\
\text { assessment, planning, implementation and evaluation. }\end{array}$ & $25.0 \%$ & $75.0 \%$ \\
\hline & $\begin{array}{l}\text { The in-country implementing partner (NGO) has the } \\
\text { capability to implement identified and planned projects in } \\
\text { the communities. }\end{array}$ & $100.0 \%$ & $0.0 \%$ \\
\hline & $\begin{array}{l}\text { Having multiple projects within a single project location } \\
\text { creates an effective way of providing technical services. }\end{array}$ & $100.0 \%$ & $0.0 \%$ \\
\hline & $\begin{array}{l}\text { The engineering design teams provide project deliverables } \\
\text { (drawings, reports etc.) in a timely manner. }\end{array}$ & $50.0 \%$ & $50.0 \%$ \\
\hline \multirow{4}{*}{ 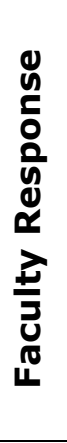 } & $\begin{array}{l}\text { There is a well-established framework for participating in } \\
\text { ESL projects that includes both depth and breadth of } \\
\text { opportunity. }\end{array}$ & $100.0 \%$ & $0.0 \%$ \\
\hline & $\begin{array}{l}\text { Having a multitude of funding opportunities for interested } \\
\text { sponsors is a strength / weakness. }\end{array}$ & $100.0 \%$ & $0.0 \%$ \\
\hline & $\begin{array}{l}\text { There is a high level of faculty participation and interest in } \\
\text { humanitarian projects. }\end{array}$ & $25.0 \%$ & $50.0 \%$ \\
\hline & $\begin{array}{l}\text { All projects have an equal level of student and faculty } \\
\text { participation. }\end{array}$ & $0.0 \%$ & $75.0 \%$ \\
\hline \multirow{6}{*}{ 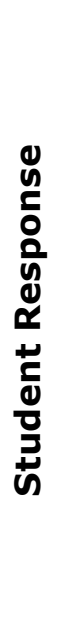 } & $\begin{array}{l}\text { Having a multidisciplinary approach to projects that } \\
\text { includes engineering and non-engineering teams is a } \\
\text { strength / weakness. }\end{array}$ & $71.4 \%$ & $28.6 \%$ \\
\hline & $\begin{array}{l}\text { There is a high level of student participation and interest } \\
\text { in humanitarian projects. }\end{array}$ & $85.7 \%$ & $0.0 \%$ \\
\hline & $\begin{array}{l}\text { There is a high level of faculty participation and interest in } \\
\text { humanitarian projects. }\end{array}$ & $71.4 \%$ & $0.0 \%$ \\
\hline & $\begin{array}{l}\text { Multidisciplinary student teams understand their roles and } \\
\text { responsibilities within a single project. }\end{array}$ & $28.6 \%$ & $57.1 \%$ \\
\hline & $\begin{array}{l}\text { Having multiple projects within a single project location is } \\
\text { an effective way of providing technical services. }\end{array}$ & $71.4 \%$ & $14.3 \%$ \\
\hline & $\begin{array}{l}\text { Student design teams feel a strong sense of accountability } \\
\text { when it comes to providing project deliverables. }\end{array}$ & $28.6 \%$ & $42.9 \%$ \\
\hline
\end{tabular}


TABLE 5

Post Project SuRVEy - StUdent FeEdBACK, N = 32

\begin{tabular}{|c|c|c|c|c|}
\cline { 2 - 5 } \multicolumn{1}{c|}{} & Strength & Weakness & Mean & STDEV \\
\hline $\begin{array}{c}\text { Application } \\
\text { Process }\end{array}$ & $\mathbf{8 7 . 5 \%}$ & $12.5 \%$ & 4.28 & 0.96 \\
\hline $\begin{array}{c}\text { Orientation } \\
\text { Preparation }\end{array}$ & $\mathbf{6 2 . 5 \%}$ & $\mathbf{3 7 . 5 \%}$ & 3.69 & 0.90 \\
\hline Logistics & $\mathbf{8 7 . 5 \%}$ & $12.5 \%$ & 4.41 & 0.71 \\
\hline Housing & $\mathbf{9 6 . 9 \%}$ & $3.1 \%$ & 4.75 & 0.51 \\
\hline $\begin{array}{c}\text { Project } \\
\text { Partner }\end{array}$ & $\mathbf{9 0 . 6 \%}$ & $\mathbf{9 . 4 \%}$ & 4.70 & 0.85 \\
\hline $\begin{array}{c}\text { Project } \\
\text { Impact }\end{array}$ & $\mathbf{8 1 . 3 \%}$ & $\mathbf{1 8 . 8 \%}$ & 4.06 & 0.95 \\
\hline $\begin{array}{c}\text { Engineering } \\
\text { Advisors }\end{array}$ & $\mathbf{9 6 . 7 \%}$ & $3.3 \%$ & 4.70 & 0.53 \\
\hline $\begin{array}{c}\text { Academic } \\
\text { Professional } \\
\text { Growth }\end{array}$ & $\mathbf{9 0 . 6 \%}$ & $\mathbf{9 . 4 \%}$ & 4.69 & 0.74 \\
\hline
\end{tabular}

\section{Breadth and Depth}

Providing both a breadth and depth of learning opportunities is important in any academic initiative. One of the challenges for an engineering service learning program is managing the breadth of opportunity that often exists in a non-curricular fashion via student clubs and volunteer groups. Volunteer organizations can be an excellent way to foster leadership skills in underclassman however ensuring that students are oriented properly and that project deliverables are relevant is a significant challenge when managing a service-learning program using student clubs. The VESL program has been strategically introducing depth of opportunity by connecting non-curricular activities with curricular initiatives. If managed correctly, student clubs can be an effective way of introducing students to the VESL program and can help them develop a better contextual understanding of the issues faced by program partners. Student SL clubs are also an excellent way to identify project leaders.

Integrated curricular-based service learning serves the purpose of introducing students to the importance of providing project deliverables. Integrated projects include mini-projects within existing core-coursework as well as designated elective courses where students work on a single project for an entire semester that reinforces key engineering concepts. Mini projects within core classes often includes two lectures, one to introduce the project within the framework of the course and another to start the project with the class and then turn it over to the students in the form of an assignment. It is important that the scope of the mini project is specified clearly and that the project partner understands the nature of the assignment.

In Fluid Mechanics, mini projects are often used for the purposes of design review. One particular example entails a renewable energy project for a rural community in Nicaragua where the project partner was proposing to install a micro hydro electrification plan for power production. This project was planning to capture the energy of falling water by constructing an intake and a 10-in penstock pipe to deliver water for a distance of 1 kilometer and an elevation difference of 80 meters to a pelton turbine and generator. Students involved with this mini 
project were asked to complete a design review of the proposed project in order to optimize the penstock design. By understanding the power needs of the community and projecting the population growth rate, the students could back calculate the flow of water needed after accounting for losses throughout the system. They could then determine if the 10-in penstock pipe diameter was sufficient to deliver the flow and pressure needed to provide the energy needs of the area.

Another important aspect of VESL is providing depth of opportunity. The first opportunity for students to engage in various projects is through designated courses where engineering service learning is the subject of a semester long project. These courses challenge our teams to think holistically about engineering when students realize the importance of assumptions and that many engineering problems do not have clearly defined constraints. Water Resources Engineering Design is a technical elective where students work on a semester long project that focuses on water supply issues in developing communities. In the Fall of 2013 students worked on a water resources master plan for a small town in Panama and students are presently working on a project for rural villages in Madagascar. Gravity Driven Water Networks is also a technical elective where students learn about the computational modeling and optimization of water delivery systems. In the past, students have worked on project for rural communities in Nicaragua and they are presently designing water-delivering systems for the same project area in Madagascar.

Students also have the opportunity to engage in projects for an entire year through senior design capstone courses. These student-driven initiatives include projects in humanitarian technology, water resources, transportation, agricultural mechanization, remote communications and structural design. Students involved with a VESL senior design project work directly with partners to define the scope of a project and create a schedule of project deliverables. They also identify the need for and plan field assignments where students can spend one to two weeks working with the in-country partner team to collect necessary information about the project. Examples of ongoing projects include; the design of a pre-school for a rural community in Cambodia where students were challenged by the need to integrate the building design with educational initiatives related to health and hygiene. Also in Cambodia, design teams worked with experts in the field of un-exploded ordnance disposal on the design of a low-cost remote control vehicle that could complete a number of field operational activities like photographing an area of concern, excavating an ordnance or setting small charges (see below case for more details). In Nicaragua, senior design projects include low-cost medical devices, telemedicine for rural health clinics and water treatment technology. In Panama, recent capstone projects have included the design of a bridge for rainy season flooding and a reservoir for storing water supply for dry-season demand.

Further depth is provided for the VESL leadership team through the use of Summer Service Internships (SSI). Students who want to fully immerse themselves in the VESL experience are encouraged to apply to work with one of our partners through the SSI program. These students are tasked with working with project partners for an 8-week period and assisting them with their regular development activities. SSI students are also asked to work with a faculty member in engineering to help them prepare course materials and to help liaison with faculty and students who are working on projects in classes. These students often take on a team leader position within a senior design capstone class because they have established good relationships with the partner, and they play a critical role on the team it that they understand the local context of the problem better than anyone else in the class. 
It is not unusual for some students who have participated in VESL activities to seek out volunteer opportunities beyond graduation. One of the challenges for engineers who are interested in international humanitarian projects is that existing volunteer programs do not have technical opportunities for engineers. For this reason, Year of Service assignments have been created for students who want to gain more experience working internationally to help improve the quality of life for people living in developing communities. These opportunities are created on a case-by case basis and require a lot of coordination between all program stakeholders. The time spent however in arranging volunteers valuable as, they add continuity for the program and fill a critical role in that they help the partner to facilitate and implement projects that are design by VESL teams.

The involvement of graduate students and research projects are a critical part of the VESL program. With the increasing popularity of distance learning, it is not unusual for graduate students to spend significant time in the field working on research projects associated with international development and sustainability. Graduate students participate in both curricular and non-curricular activities. During the fall semester, they are expected to volunteer with a project through a country-coordinator position that has been created on the student club. In this role, they lead meetings and communicate with the partner and the faculty advisor about the project scope and schedule of deliverables. During the spring semester, interested graduate students can enroll in a project-based international sustainability course where they work with undergraduate students on finalizing deliverables for the year and a research project that focuses on sustainable development issues. Research projects include using a framework, which is known as STEEP Sustainability where students evaluate past and ongoing projects from a Social, Technical, Environmental, Economic and Political point of view. A graduate research fellowship has also been created where project partners and other funding entities can sponsor a research project. To date, three fellowships have been sponsored that focus on Sustainable Water Infrastructure initiatives in Nicaragua, Panama and Madagascar. Figure 4 shows a summary of the most recent academic year in terms of the breadth and depth of student participation in the VESL program.

Graduate research projects on sustainability are an important part of demonstrating bestpractices in engineering service learning. At the present time these initiatives focus on the sustainability of community managed water supply infrastructure because of the number of projects that include water system design. Previous research has however, included the sustainability of renewable energy systems as well as innovation and entrepreneurship. In addition to graduate research projects in sustainable engineering, VESL is also working with a PhD student in education who is researching the value of Engineering Service Learning from the community's perspective. The reference section of this report lists various papers and conference proceedings which have been published as a result of this work. 
Case Study Examples

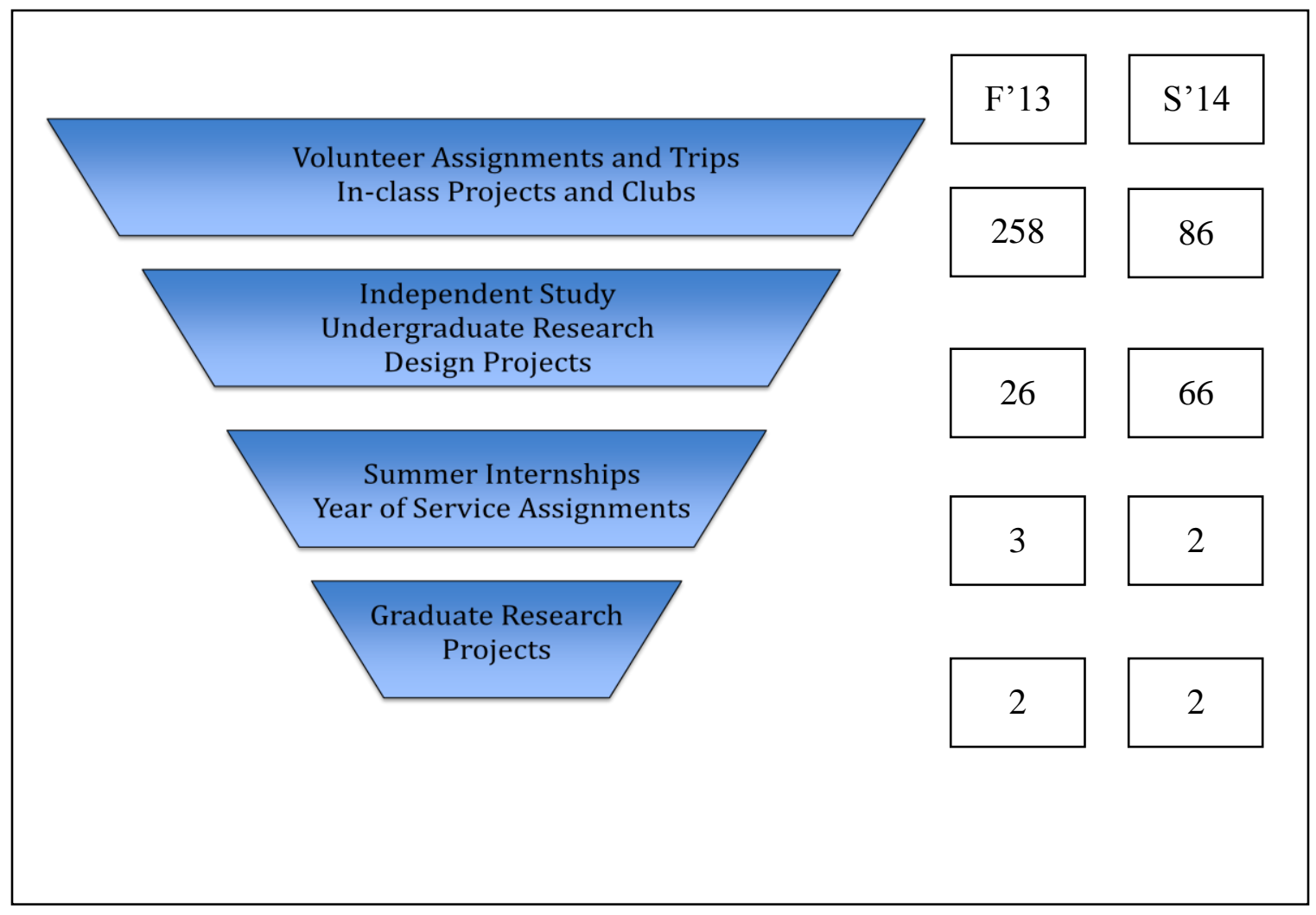

FIGURE 4

BREADTH AND DEPTH OF PARTICIPATION, No. OF STUDENT F'13/S'14

\section{Ongoing Collaborations: Cambodia Project}

The VESL program is currently involved in projects in a number of countries. Excellent examples of this work are the projects underway in Cambodia, which span everything from robotics to structural design. In the following section, the details of these programs are presented. The programs in Cambodia have two key project partners:

1) The Caramanico Foundation Cambodia (CFC) - The CFC organization was founded in 2012 with the objective of improving education for developing communities in the remote province of Rantankiri, Cambodia.

2) The Golden West Humanitarian Foundation (GWHF) - The GWHF is recognized by the international humanitarian ERW remediation community as one of the premier nongovernmental organizations for the research, development, and implementation of solutions to address this sector's most difficult technical challenges.

\section{CFC Projects}

In the Fall semester of 2011, the College of Engineering at Villanova University was approached by an alumni who had been involved with a non-government organization that was 
building schools in Cambodia. At the same time, this alumnus had created a team of volunteers from the Philadelphia area who were fundraising for school construction projects in Cambodia. After some initial discussion, the VESL group at Villanova decided to send a small team of students and faculty to investigate the feasibility of incorporating some future projects into various engineering curriculum. During the Fall Semester of 2012, a student team was created within the Structural Engineering program who worked with various in-country partners as well as the Caramanico Foundation to design a pre-school to integrate learning activities for children related to health and hygiene awareness programs. The project was completed in the summer of 2014 and now has over 50 students in the school.

\section{GWHF Projects}

Approximately 3 years ago, the authors were on a flight from Taipei, Taiwan to Phnom Penh, Cambodia with a group of 3 students on an exploratory trip for the Caramanico projects. On that flight, the authors met one of GWHF's senior EOD technicians. He invited them to tour their research and development facility and the VU-GWHF collaboration was born.

This strong collaboration has primarily focused on senior design projects centered on research and development of technologies to support GWHF's work. Example projects are as follows.

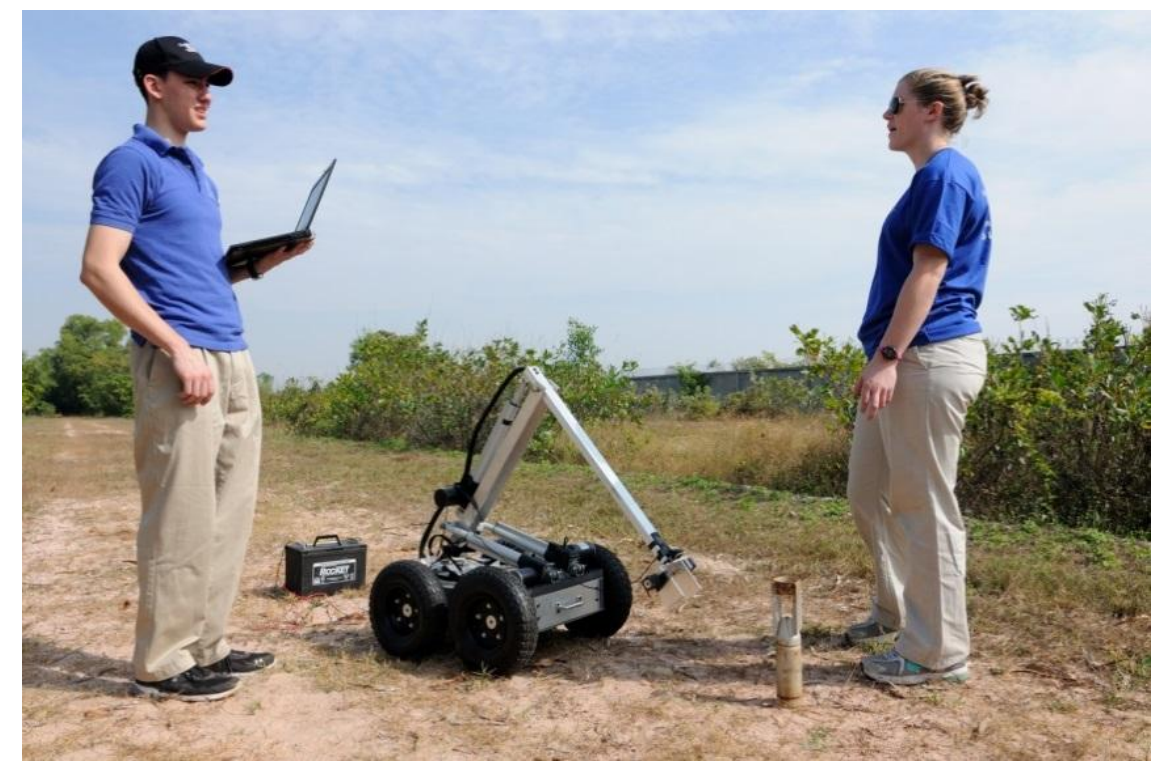

FIGURE 5

VESL STUDENTS PERFORM A FIELD TEST OF THE EOD ROBOT AT THE GWHP RESEARCH FACILITY IN KAMPONG CHHNANG, CAMBODIA

Project 1: Low-cost EOD Robot Problem Statement: EOD robots are a critical tool for many EOD operations, however EOD robots currently on the market are too expensive for use in the developing world. Students at Villanova have been working on this problem for the past two years. Using low-cost electronics, materials, and standard machining techniques, a low cost EOD platform has been developed (see Fig. 2). It should be noted that cost was also reduced by identifying the critical functionality of the EOD robot and designing the platform with this in mind. 
Project 2: Ordnance Burning Filtration Hood Problem Statement: The ability to safely burn explosives is a hugely valuable tool in ordnance stockpile destruction operations. At present, environmentally safe methods are only available at large-scale industrial demilitarization plants. This leaves no clean solution for the majority of small-scale stockpile destruction missions in post-conflict developing nations. Students at Villanova developed a portable filtration hood that theoretically meets the design specifications. The second iteration of this project will include the construction and testing of a prototype.

Student Involvement and Outcomes: Over the last 2 years, a total of 15 students have taken part in these projects with PI Clayton and 8 students travelling to Cambodia to take part in a design review and engage in an international engineering experience. In addition, 1 student interned at GWHF for an entire summer. Anecdotally, these international project experiences have affected the students in a meaningful way: 5 have entered the armed forces ( 3 in the Navy nuclear program's highest engineering position and one in EOD) and 6 going on to pursue advanced degrees in engineering.

\section{Lessons Learned: Philippines Project}

In 2009, Villanova University students and faculty identified a rural micro-hydroelectric system in North Philippines, located in the village of Maggok in the province of Ifugao. The system was designed and implemented in 2005 by a local organization with technical input from provided by a British volunteer. Whereas the original designs were technically accurate, significant mistakes were made during the implementation. Between 2005 and 2009, there was a change in leadership within the local organization that included restructuring and renaming the organization. As a result, by 2009 , the existing micro-hydro system was in a very bad condition and required civil, mechanical and electrical engineering expertise to render it operational again. Over the span of few years, Villanova faculty and students worked with the local partner to deploy a new turbine, completely rebuild the powerhouse and provide funding for a new generator and load controller. However, multiple factors came into play to make this a challenging partnership/project.

Some of these reasons are:

1. Flaws in the design and manufacturing required onsite repairs to be made to the newly revised turbine.

2. The local partner's goals changed over time and the rehabilitation project was not a priority.

3. The local community had a long history with the micro hydro system and a there was a lack of confidence that the rehabilitation would be successful.

4. A typhoon destroyed a large section of the penstock pipe during the rehabilitation causing the project to be put on hold since 2011.

The failure to complete the rehabilitation to this day shows that projects and partnerships in such settings can be very complex. On the technical side, the original system was poorly designed from the start and neither the local partner nor Villanova faculty/students had the capacity to implement a rehabilitation project in this remote setting. Thus the local organization was not the best partner, specifically as it related to project implementation. On the local partner side, the long duration of the rehabilitation project was detrimental to the overall success. Rural organizations are mostly driven by project-specific funding and thus when the funding dwindled for the rehabilitation project, the organization shifted its focus to other projects. Finally, on the 
community engagement side, the partner was not viewed well by some of the local community members because of the history of the initial project being implemented poorly. There were some complaints from the locals about how the initial system was constructed and how things were managed. That information was discovered long after the partnership between Villanova and the organization was made official. Finally, the typhoon damage highlights the fact that there is a very high uncertainty in remote settings. Certain events can occur that are either completely unpredictable or too complex to understand.

Villanova used the lessons learned and experience of this partnership/project to improve its approach to similar projects. Villanova now focuses on providing technical support to local partners while ensuring that the local partners have enough capacity and expertise to implement those projects. Moreover, students now engage in specific projects with local partners and are given certain a timeline and deliverables. The local partner is expected to take the lead on identifying relevant projects within the community where Villanova faculty and students can provide technical assistance. Adopting this bottom up approach ensures that the projects come from within the community and are well rooted to ensure maximum impact.

\section{List of Publications}

The below list of publications are being presented to address a concerns within the engineering academic community related to service learning. The first concern is that service learning projects are not rigorous enough to warrant attention within engineering programs. To this concern, the authors of this paper would agree that traditional service learning that tends to focus on providing free labor to organizations in need and then connects the experience to learning outcomes associated with understanding poverty would not be rigorous enough to reinforce engineering fundamentals. When service learning is initiated within an engineering program however, it includes input from technical professionals as well as engineering faculty, and it can be an excellent mechanism for improving learning within engineering programs. In addition to this, a well-organized engineering service learning program can also provide motivation that goes beyond the classroom and can help to reinforce the importance of life-long learning particular for marginal students who are not always motivated by grades.

The second concern that is often raised in engineering academia is that engineering service learning does not provide the type of recognition that academic committees value when evaluating the merit of promotion and tenure. Very often in academia, promotions are given based on course evaluations, research, grants and publications. Whereas these criteria for evaluating tenure are very important within academia, they are not mutually exclusive of the experiential learning that is provided by engineering service projects. As shown by this list of publications, engineering service projects can improve both the teaching and learning experience within a classroom, and they can also lead to grants and field related research projects that contribute to larger, global development initiatives. In addition to this, when the focus of international service learning projects is on partnerships rather than projects, research and grant opportunities are more prevalent as, many funding agencies see value in university partnerships with international NGOs. 
Ermilio, J., Cain, D., Pattison, I., Sohail, M., (2014) "Performance Evaluation of Community Managed Water Supply Infrastructure", $37^{\text {th }}$ Annual WEDC International Conference, Referred Paper, Sustainable Water and Sanitation Services for All in a Fast Changing World.

Reynolds, N.P. (2014), "What Counts and Outcomes? Community Perspectives of and Engineering Partnership”, Michigan Journal of Community Service Learning, Fall.

M. Kabalan, B. Anabaraonye (2014), "Solar Photovoltaic versus Micro-Hydroelectricity: A Framework for Assessing the Sustainability of Community-run Rural Electrification Projects". Conference Proceeding IEEE GHTC.

M. Kabalan, D. Tamir, P. Singh (2014), "PLC load controller for micro-hydroelectric systems in rural settings" Conference Proceedings IEEE-GHTC.

M. Kabalan, D. Tamir, P. Singh (2014), "Failure Analysis of Microhydroelectric sites in the Province of Ifugao, Philippines” Conference Proceedings IEEE-IHTC, Canada.

M. Kabalan, D. Tamir, P. Singh, "Community Engagement for the Development of a Microhydroelectric site in Ifugao, Philippines," Conference Proceedings IEEE-IHTC, Montreal, Canada, 2014.

M. Kabalan, D. Tamir, J. Ermilio, P. Singh and J. Klingler (2013), "Electricity for Rural Communities of Ifugao, Philippines”. Open 2013 conference, Washington, DC.

D. Tamir, M. Kabalan, J. Ermilio, P. Singh, and J. Klingler (2012), "From Students to Social Entrepreneurs in Ifugao, Philippines”. Open 2012 conference, San Francisco, CA.

Jones, G., Ermilio, J. (2011). “Gravity-Driven Water Flow in Networks: Theory and Design”. John Wiley and Sons, Inc.

O’Brien, J. (2010), "Service Learning in the College of Engineering at Villanova University", American Society for Engineering Education, Annual Conference, Learning by Doing.

Dinehart, D. W. and Gross, S. P. (2010) "A Service Learning Structural Engineering Capstone Course and the Assessment of Technical and Non-technical Objectives", Advances in Engineering Education, a Journal of Engineering Education Applications, Vol. 2, No. 1, spring.

Ermilio, J., Klingler, J., Singh, P., (2010), “Implementing Sustainable Entrepreneurial Projects in Ifugao, Philippines. Peer Reviewed Paper Series, National Collegiate Inventors and Innovators Alliance.

Dinehart, D. W. and Gross, S. P. (2007) "Development, Implementation, and Outcomes of International Service Learning in Structural Engineering", Proceedings of the National Capstone Design Course Conference, Boulder, CO, June.

Dinehart, D. W., Gross, S. P. and Yost, J. R. (2005) "Development of a Model Program in 
Structural Engineering", Academics: Reflections of Teaching and Learning at Villanova, Volume 2, Number 1.

Dinehart, D. W. and Gross, S. P. (2002) "Teaching Constructability Using Third-World Constraints", Proceedings of the 2002 American Society of Engineering Educators Annual Conference, Montreal, June.

Gross, S. P. and Dinehart, D. W. (2002) "Engineering in a Third World Country", Occasional Papers: Service Learning, Villanova University Office of Mission Effectiveness, Vol. 4. (short essay)

\section{ACKNOWLEDGEMENTS}

This work has been supported by the various departments as well as the Dean's office in the College of Engineering. The authors acknowledge the unique nature of academia at Villanova that provides for these types of experiential learning opportunities and challenges the department chairs, associate deans and deans of other colleges to get dirt on their shoes from working with students and communities in developing countries. In the College of Engineering at Villanova University the over 70 percent of department chairs and deans have engaged in international service learning projects. 